\title{
The Relationships Between Perceptions Of Supervisor, Trust In Supervisor And Job Performance: A Study In The Banking Industry
}

Betty J. Birkenmeier, Texas A\&M University, USA

Pierre-Yves Sanséau, Grenoble Ecole de Management, France

\begin{abstract}
The purpose of this study is to investigate the relationship between the perceptions a front line employee has of their immediate supervisor, the trust the front line employee has in this supervisor, and an employee's job performance. Data were collected from 457 employees holding customer contact positions at community and regional banks located in several states in the southern part of the United States. The findings of the study indicate that there is strong correlation between the perceptions an employee has of their supervisor and the trust the employee has in their supervisor for Customer Service Representatives. Furthermore, it was found that there was, at best, a weak correlation between perceptions of supervisor and job performance.
\end{abstract}

Keywords: Front Line Employee; Job Performance; Perceptions of Supervisor; Trust in Supervisor

\section{INTRODUCTION}

n 2012, 79,9\% of the workforce in the United States was employed in the economy's service sector (US Department of Labour, 2015). Each employee who is on the front line, facing the customers, plays an instrumental role in their organization's ability to deliver quality service (Evenson et al., 1999; Zeithaml \& Bitner, 2009). Front line employees serve as "ambassadors" for their organizations so human resource management, therefore, has a crucial role to play to ensure that such employees have the skills and knowledge needed to provide a high level of customer service (Sandburg, 2000; Schneider \& Bowen, 1985). The purpose of this study is to investigate the relationship between the perceptions front line employees have of their immediate supervisor, the trust they have in those supervisors, and front line employees' job performance. The survey participants in our study were tellers and customer service representatives (CSRs) at community and regional banks. It has been noted that "trust is often perceived to be the lubrication that makes it possible for organizations to work" (Bennis \& Nanus, 1985: 43). It has also been defined as an integrative mechanism creating and sustaining social systems (Blau, 1964), "the source of increased efficiency and effectiveness" (Golembiewski \& McConkie, 1975), and also as an exchange deepener and as uncertainty reducer (Colquitt et al., 2012).

\section{LITERATURE REVIEW}

\section{Trust}

The concept of trust has been studied in a variety of disciplines (e. g., management, sociology, and economics) (Bhattacharya et al., 1998) at the individual or the institutional level (Lewicki \& Bunker, 1995). Researchers working in these areas have all commented on the importance of trust in transactions between various individuals or groups. Thus Blau (1964: 99) claimed trust is "essential for stable social relationships" while Golembiewski \& McConkie (1975: 131) observed that "There is no single variable which so thoroughly influences interpersonal and group behavior as does trust". Numerous researchers stress that positive interactions between parties are very important and directly affect the levels of trust the parties have in each other (Kramer \& Tyler, 1996; Lewicki et al., 
1998); and various scholars have noted that an employee's trust is a crucial variable that impacts organizational efficiency, effectiveness, and performance (Dirks \& Ferrin, 2002; Tzafri et al., 2004). Unless trust is present, an organization will find it challenging to develop a cohesive culture and cooperation among employees will be less likely (Ferrin et al., 2007; Vlaar et al., 2007).

It has been noted that trust is not a static phenomenon, but can increase or decrease depending on environmental factors as well as the parties' interactions (Bijlsma-Frankema \& Costa, 2005). Various researchers have found that trust will increase if a trustee lives up to "expectations of beneficial behaviour" but, by the same token, the trust a trustor has in a trustee will decrease if such expectations are not fulfilled (Lewicki \& Bunker, 1996: 125).

As a psychological state, trust can assist in how one person views their relationship with another, especially in situations that entail vulnerability or risk (Dirks \& Ferrin, 2001). Gould-Williams \& Davies (2005) note that, when employees view their supervisor's actions positively, they tend to respond with behaviors and attitudes that are important to the organization. Neves and Caetano (2009) examined trust in supervisors from the perspective of how employees' affective commitment to organizational change influences three work outcomes (performance, turnover, and organizational citizenship behaviors) and found that trust fully mediated these relationships. Their findings show that when employees are more affectively committed, they trusted their supervisors more which, in turn, resulted in an increase in performance and citizenship behaviors and at the same time a decrease in employee turnover.

\section{Front Line Employees and Job Performance}

Relevant research with respect to the human resources/performance relationship dates back to the 1950s and 1960s. The findings of French and Snyder (1959) indicate that, when leaders were viewed as attractive and as expert, both the opinions and performance of their subordinates were greatly affected in a positive manner. In a similar study, Bachman et al., (1968) findings revealed that the performance effectiveness of subordinates increased in proportion to how attractive and expert they viewed their subordinates. Gagnon \& Judd (2004) investigated the relationship between employees' perceptions of their supervisors and employee attitudes (i.e. trust) and job performance. The overall finding of this research is that when employees perceive they are in a supportive relationship with their supervisor the outcomes are higher levels of job satisfaction, job performance, and organizational commitment (Gagnon \& Judd, 2004).

The success or failure of a service exchange depends heavily on the performance of the service employee involved (Bowen, 1990; Puay et al., 1999). To keep customers coming back, it is important that front line employees meet customers' needs in a way that stands out in the minds of the customers (Crosby \& Johnson, 2002). Yet, as noted by some researchers there has been little research that investigates the factors that lead to customer loyalty in service settings (Pritchard et al., 1999; nor is much known about the techniques that can be used to improve the performance of front line employees in such settings (Ellinger et al., 2007; Hansen et al., 2003).

\section{Job Performance and Trust in Supervisor}

This research proposes that trust in a supervisor is the link that connects human resource management to job performance. According to Tzafrir \& Gur (2007), there have not been any studies investigating the relationship between HRM practices and service quality that have used trust as a mediating variable. Their study focused on this relationship by examining employee perceptions of service quality in a healthcare organization and produced three findings that are relevant for our study: (1) that there is a significant and positive relationship between human resource practices and perceptions of service quality; (2) that there is a significant and positive relationship between human resource practices and trust; and (3) that there is a significant and positive relationship between trust and perceptions of service quality. Tzafrir \& Gur (2007) note that the results imply that the trust employees have in their supervisors directly affects service quality.

Nyhan (2000) has proposed that one of management's critical tasks is to develop trust where front line employees interact with service users. The role of the supervisor is crucial in ensuring that employees are able to competently perform their jobs (Rowold, 2008). For employees, this means that they have to be able to trust that their supervisor 
will ensure they have sufficient training so that their job performance will be of a high caliber. In addition, their perceptions of their supervisors also affect the trust relationship. The ability, benevolence, and integrity of a supervisor can enhance or diminish the trust employees have in them (Butler, 1991; Mayer \& Gavin, 2005).

\section{Antecedents to Trust: Ability, Benevolence, and Integrity of Supervisors}

Prior to 1995 , researchers used a variety of approaches to identify factors that could be antecedents of trust (Mayer \& Gavin, 2005). Some researchers found that the ability, benevolence, and integrity of a supervisor form the basis for employee perceptions of the supervisor's trustworthiness (Butler, 1991; Cho \& Ringquist, 2010; Mayer \& Gavin, 2005). Ability, benevolence, and integrity have been examined individually, together, and as part a larger group of antecedents (Mayer \& Gavin, 2005). Clark and Payne (1997) identified the attributes integrity, openness, competence, and consistency/fairness while Butler (1991) identified a larger group of 10 antecedent behaviors: availability, competence, consistency, discreteness, fairness, integrity, loyalty, openness, keeping promises, and receptivity. Some research findings indicate that employees use varied combinations of these antecedent behaviors to evaluate their supervisors (Clark \& Payne, 1997; Mayer \& Gavin, 2005; Morgan \& Zeffane, 2003). Integrity, benevolence, and ability are factors that demonstrate trustworthiness; and, as such, serve as building blocks for the formation of trust (Cho \& Ringquist, 2010). The perceptions (i.e. antecedent behaviors) that are examined in the current research are the supervisor's: ability, benevolence, and integrity (Mayer et al., 1995; Tan \& Tan, 2000).

Ability is defined as an "employee's perception of the supervisor's relevant skills, competencies, and characteristics" (Tan \& Tan, 2000). Ability is also thought to be a fundamental component of trust by Cook \& Wall (1980). In an employee-supervisor relationship the supervisor needs to possess the required skills and aptitude to positively impact employee perceptions (Davis et al., 2000).

Benevolence is the "extent to which a trustee is believed to want to do good to the trustor, aside from an egocentric motive" (Mayer et al., 1995). It has been portrayed as a "demonstration of concern" and involves actions by supervisors that demonstrate their (1) consideration, (2) sensitivity, and (3) protecting the interests of their employees (Sherwood \& DePaolo, 2005). A supervisor is more likely to be trusted when an employee is convinced the supervisor will expend extra effort on behalf of this employee (Davis et al., 2000).

Integrity is defined as the "extent to which the supervisor's actions reflect values acceptable to the subordinate" (Mayer et al., 1995). Similarly, Davis et al. (2000) argue that when a supervisor conforms to a set of principles of which an employee approves, that employee then believes their supervisor has integrity.

\section{Hypotheses}

A search of the literature indicates that there is a general lack of research with respect to the link between HR practices job performance. A number of researchers have suggested that while human resource practices are likely developed by human resources departments, it will be front line managers who are responsible for implementing those practices (Purcell, 1999; Zohar \& Luria, 2004). Research by Purcell (1999) found that, in analyzing the relationship between employee performance and HRM, the role of the first line manager has been "neglected" and that there has been little research on the crucial role first line managers play in the HRM - performance equation.

There is another gap in the literature that exists with respect to the service sector. Organizational scholars have not been inclined to focus on service settings, despite the fact that about $80 \%$ of the U.S. Gross Domestic Product (GDP) was produced by private service sector organizations in 2006 (Zeithaml \& Bitner, 2009) nor have they given service settings much attention in spite of the fact that there can be significant differences between the production and the delivery of products and of services (Schneider et al., 2007).

Three hypotheses have been developed based on these literature gaps and the authors' interest in examining the question: What is the relationship between front line banking industry employees' perceptions of a supervisor, their level of trust in that supervisor, and their job performance in banks located in the southern part of the United States? 
The first hypothesis is based on the implication that the level of trust an employee has in their immediate supervisor will affect the employee's job performance. Blunsdon and Reed (2003) proposed that overall levels of trust that employees have in their supervisors could be affected by various aspects of the workplace. More specifically, they found that features of the workplace such as workplace rules, the use of various work practices, how decisions are made as well as how information is dispensed affect levels of trust between employees and supervisors. They further found that these levels of trust are formed independently of the personal qualities possessed by the supervisor and the employee (Blunsdon \& Reed, 2003). Eisenberger et al., (1990) have proposed that employee trust in supervisors develops from managerial actions in conjunction with the human resource activities of the organization (i.e. training) and that this relationship then affects the job performance of employees. Thus,

H1: There will be a nonzero linear correlation between trust in a supervisor and job performance.

The second hypothesis is based on the implication that the perceptions employees have of their supervisors will affect the job performance of these employees. Previous research by a number of researchers has illustrated the importance of this relationship, noting that (1) the importance of how HRM practices are implemented in an organization is often underestimated, and (2) the assessment and improvement of employees is highly dependent on their immediate supervisor playing a key role in the assessment and improvement process (den Hartog \& Verburg, 2004; Locke \& Latham, 2002). Gagnon \& Judd (2004) found that there will be higher levels of job satisfaction, job performance, and organizational commitment when employees perceive they have a supportive relationship with their supervisor. Thus,

H2: There will be a nonzero linear correlation between the perceptions of supervisor and job performance.

The third hypothesis is based on the implication that analyzing how an employee views the ability, benevolence, and integrity of their supervisor can provide valuable insight into perceptions front line employees have of their supervisors. For example, when a supervisor has the skills to show they understand issues that are important to employees, and then go on to resolve those issues satisfactorily for employees, the outcome should be that their perceptions of the supervisor's ability are positively affected. Wright et al., (2003) argue that it is essential that employee perceptions be used to measure human resource practices. Thus,

H3: There will be a nonzero linear correlation between the perceptions of a supervisor and the trust an employee has in the supervisor.

\section{Methodology}

This empirical research study utilizes a survey methodology in a quantitative framework. An employee survey was used to collect individual level perception data on the relationships between the perceptions of a supervisor, trust in the supervisor, and job performance. All items selected for this study are taken from well-established scales that have been previously used by researchers working in one or more of the areas of perceptions of supervisors, trust, or job performance (Babin \& Boles, 1996; Boshoff \& Tait, 1996; Clark, Dobbins \& Ladd, 1993; Clark \& Payne, 1997; Cummings \& Bromiley, 1996; Garbarro \& Athos, 1976; Magenau \& Hunt, 1996; Nyhan, 1997; Schorman et al., 1996; Tzafrir \& Dolan, 2004).

The target population for this study was front line employees employed in banks in the southern part of the United States (a sample which was chosen for convenience). Thirteen of the fourteen participating banks are community banks and the other is a regional bank. All employees who work in customer contact positions were asked to participate. A total of 736 questionnaires were distributed, of which 458 were returned, giving an overall response rate of $62 \%$. One survey was found unusable for data analysis. $87.4 \%$ of the respondents were female and $12.5 \%$ male. The two largest groups of front line employees represented were tellers $(47.5 \%)$ and customer service representatives (CSRs) $-24.3 \%$. 


\section{RESULTS}

The focus of the study is on tellers and customer service representatives. A stepwise regression analysis was conducted in order to investigate the relationship between the dependent (criterion) variable and the independent (predictor) variables. With this approach questions can be asked as to what is/are the best predictor(s) of job performance? The predictor variables for this research are employees' perceptions of their supervisors, and their trust in their supervisors. The stepwise regression analysis was conducted separately for the two groups of employees: tellers and customer service representatives. The results for tellers are discussed first and then the results for customer service representatives are discussed.

\section{Tellers}

The descriptive statistics for tellers is found in Table 1 and the correlations are in Table 2. Table 3 contains the model summary. The stepwise regression ANOVA results can be found in Table 4. This is followed by the Coefficients in Table 5.

Table 1. Descriptive Statistics

\begin{tabular}{l|c|c|c}
\hline & Mean & Std. Deviation & N \\
\hline Job Performance & 5.746 & .989 & 196 \\
Trust & 3.764 & .682 & 196 \\
Perceptions of Supervisor & 5.131 & .767 & 196 \\
\hline
\end{tabular}

Table 2. Correlations

\begin{tabular}{l|l|ccc}
\hline \multicolumn{2}{l}{} & Job Performance & Trust & Perceptions of Supervisor \\
\hline \multirow{3}{*}{ Pearson Correlation } & Job Performance & 1.000 & .054 & .250 \\
& Trust & .054 & 1.000 & .020 \\
& Perceptions of Supervisor & .250 & .020 & 1.000 \\
\hline \multirow{3}{*}{ Sig. (1-tailed) } & Job Performance &. & .228 & .000 \\
& Trust & .228 &. & .391 \\
\hline \multirow{3}{*}{$\mathrm{N}$} & Perceptions of Supervisor & .000 & .391 &. \\
& Job Performance & 196 & 196 & 196 \\
& Trust & 196 & 196 & 196 \\
\hline
\end{tabular}

Table 3. Model Summary

\begin{tabular}{lccccc}
\hline & Model & $\mathbf{R}$ & R Square & Adjusted R Square & $\begin{array}{c}\text { Std. Error of the } \\
\text { Estimate }\end{array}$ \\
\hline 1 & $.250^{\mathrm{a}}$ & .063 & .058 & .960 \\
\hline a. & Predictors: (Constant), Perceptions of Supervisor & & & &
\end{tabular}

Table 4. ANOVA Results

\begin{tabular}{llccccc}
\hline & Model & Sum of Squares & df & Mean Square & F & Sig. \\
\hline \multirow{2}{*}{1} & Regression & 11.942 & 1 & 11.942 & 12.955 & $.000^{\mathrm{b}}$ \\
& Residual & 178.836 & 194 & .922 & & \\
& Total & 190.778 & 195 & & & \\
\hline
\end{tabular}

a. Dependent Variable: Job Performance

b. Predictors: (Constant), Perceptions of Supervisor

Table 5. Coefficients

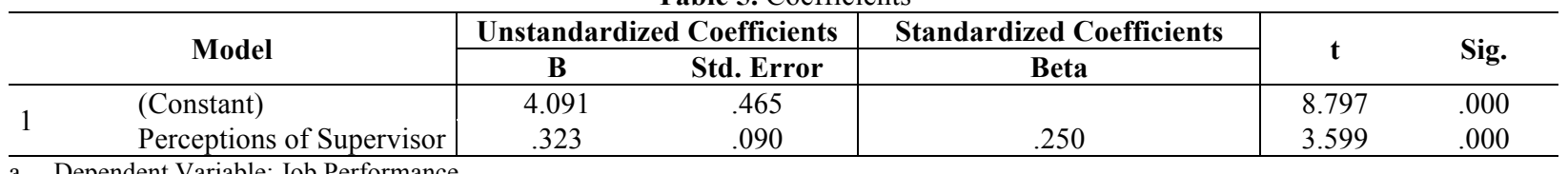

a. Dependent Variable: Job Performance

Copyright by author(s); CC-BY 
H1: There will be a nonzero linear correlation between trust in a supervisor and job performance. A Pearson correlation coefficient was calculated for the relationship between trust in a supervisor and job performance. It was found that $\mathrm{r}=.054$, the $\mathrm{p}$ value $<.228$, and the d.f. $=194$. This does not indicate a nonzero linear correlation between trust and job performance so $\mathrm{H} 1$ is not supported.

H2: There will be a nonzero linear correlation between perceptions of supervisor and job performance. It was found that $\mathrm{r}=.250$, the $\mathrm{p}$ value $<.001$, and the d.f. $=194$. There is weak positive support for perceptions of supervisor and job performance. Therefore, a higher perceptions of supervisor score tends to indicate a higher job performance score.

H3: There will be a nonzero linear correlation between perceptions of supervisor and trust in supervisor. It was found that $\mathrm{r}=.020$, the $\mathrm{p}$ value $<.391$, and the d.f. $=194$. This does not indicate nonzero linear correlation between perceptions of supervisor and trust in supervisor.

\section{Customer Service Representatives}

The descriptive statistics for customer service representatives is found in Table 6 and the correlations are in Table 7. Table 8 contains the model summary. The stepwise regression ANOVA results can be found in Table 9. This is followed by the coefficients in Table 10 .

Table 6. Descriptive Statistics

\begin{tabular}{lccc}
\hline & Mean & Std. Deviation & N \\
\hline JobPerf & 6.254 & .724 & 101 \\
Trust & 5.748 & 1.177 & 101 \\
PerSuper & 6.239 & .897 & 101 \\
\hline
\end{tabular}

Table 7. Correlations

\begin{tabular}{l|l|ccc}
\hline \multicolumn{2}{c|}{} & JobPerf & Trust & PerSuper \\
\hline \multirow{3}{*}{ Pearson Correlation } & JobPerf & 1.000 & .279 & .413 \\
& Trust & .279 & 1.000 & .801 \\
& PerSuper & .413 & .801 & 1.000 \\
\cline { 2 - 5 } Sig. (1-tailed) & JobPerf &. & .002 & .000 \\
& Trust & .002 &. & .000 \\
$\mathrm{~N}$ & PerSuper & .000 & 1000 &. \\
\cline { 2 - 5 } & JobPerf & 101 & 101 & 101 \\
& Trust & 101 & 101 & 101 \\
\hline
\end{tabular}

Table 8. Model Summary

\begin{tabular}{|c|c|c|c|c|}
\hline Model & $\mathbf{R}$ & R Square & Adjusted R Square & $\begin{array}{l}\text { Std. Error of the } \\
\text { Estimate }\end{array}$ \\
\hline 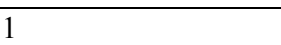 & $.413^{\mathrm{a}}$ & .170 & .162 & .663 \\
\hline
\end{tabular}

Table 9. ANOVA Results

\begin{tabular}{l|l|ccccc}
\hline \multicolumn{2}{c|}{ Model } & Sum of Squares & df & Mean Square & F & Sig. \\
\hline \multirow{3}{*}{1} & Regression & 8.934 & 1 & 8.934 & 20.324 & $.000^{b}$ \\
& Residual & 43.518 & 99 & .440 & & \\
\hline
\end{tabular}

a. Dependent Variable: JobPerf

b. Predictors: (Constant), PerSuper 
Table 10. Coefficients

\begin{tabular}{|c|c|c|c|c|c|c|}
\hline & \multirow{2}{*}{ Model } & \multicolumn{2}{|c|}{ Unstandardized Coefficients } & \multirow{2}{*}{$\begin{array}{c}\text { Standardized Coefficients } \\
\text { Beta }\end{array}$} & \multirow{2}{*}{$\mathbf{t}$} & \multirow{2}{*}{ Sig. } \\
\hline & & $\mathbf{B}$ & Std. Error & & & \\
\hline \multirow{2}{*}{1} & (Constant) & 4.174 & .466 & & 8.959 & .000 \\
\hline & PerSuper & .333 & .074 & .413 & 4.508 & .000 \\
\hline
\end{tabular}

H1: Proposes that there will be a nonzero linear correlation between CSRs' trust in their supervisor and the job performance of CSRs. A Pearson correlation coefficient was calculated for the relationship between trust in a supervisor and job performance. It was found that $\mathrm{r}=.279$, with $\mathrm{p}$ value $=.002$, and d.f. $=99$ indicating weak positive support for H1. Therefore, trust in a supervisor is correlated with customer service representatives' job performance.

H2: Argues that there will be a nonzero linear correlation between the CSRS' perceptions of their supervisor and the job performance of CSRs. It was found that $\mathrm{r}=.413$, with $\mathrm{p}$ value $<.001$, and d.f. $=99$, indicating a weak positive support for H2. The correlation between perceptions of supervisor and job performance means higher perceptions of supervisor tend to indicate a higher job performance score.

H3: Suggests that there will be a nonzero linear correlation between the perceptions of supervisor and trust in supervisor. It was found that $\mathrm{r}=.801$, with $\mathrm{p}$ value $<.001$, and d.f. $=99$, indicating a strong positive correlation between perceptions of supervisor and trust in supervisor; and thus supporting $\mathrm{H} 3$.

The stepwise regression analysis produced some interesting results in terms of variations in levels of job performance based on those of the other variables: perceptions of supervisor and trust in supervisor. There is strong positive support for the correlation between perceptions of supervisor and trust in supervisor for customer service representatives, but for tellers the analysis showed no correlation between perceptions of supervisor and trust.

\section{DISCUSSION}

We anticipated that this study would find correlations would be found between employees' perceptions of their supervisor, their trust in those supervisors, and the job performance of employees. A stepwise linear regression was used to determine which of the variables (trust in or perceptions of supervisor) should be used in a linear model to predict job performance. The analysis indicated that job performance and perceptions of supervisor be included in the model and trust be excluded. Two contributions to the literature emerged from this research. First, the stepwise regression analysis indicated there was a weak positive relationship between perceptions of supervisor and job performance for both tellers and customer service representatives. Second (while not in the model), the stepwise regression analysis indicated a significant positive relationship between perceptions of supervisor and trust in supervisor for customer service representatives but the stepwise liner regression did not indicate a nonzero linear correlation between perceptions of supervisor and trust in supervisor for tellers.

\section{Perceptions of Supervisor and Job Performance}

To evaluate whether a supervisor can be trusted, subordinates will examine a number of attributes of the supervisor and then form their perceptions of them. One attribute that is important to subordinates is integrity (Dasgupta, 1988). Two other antecedents of trust that subordinates also examine are the benevolence and the ability of the supervisor (Mayer \& Gavin, 2005). Researchers such as Mayer and Davis (1999), and Mayer and Gavin (2005) have found that integrity, benevolence, and ability are important components of trustworthiness and all three aid in the prediction of subordinates' trust in their supervisors. The same three attributes were selected for the perceptions of a supervisor in the front line bank employee survey. The findings of the stepwise regression analysis in the present study regarding perceptions of supervisor and trust in a supervisor are supported in all of the abovementioned research. 


\section{Supervisor Relationship with Tellers and CSRs and Job Performance}

In a study conducted by den hartog, Boslie, \& Paauwe (2004: 561) it was noted that "the role of direct managers and supervisors in the (fair) implementation of HRM practices is often underestimated" and that "managers play a key role in assessing and improving employee performance". Other researchers (Colquitt et al., 2001; Locke \& Latham, 2002; Rhoades \& Eisenberger, 2002) have made similar observations. The correlation analysis in our study of tellers and CSRs indicated a weak positive correlation between perceptions of supervisor and job performance. In banking there is a strong emphasis on training due to the need to provide good customer service, to handle all transactions effectively and efficiently, and to stay in compliance with all federal and state banking regulations. The heavy emphasis on the service and regulatory climates means that the importance of their training is likely to be at the forefront of all actions taken by tellers and CSRs.

Comments from tellers and CSRs in the survey instrument parallel the literature findings that, for the most part, training for these employees is handled by the banks' human resources function. In this environment it would appear that the role of the supervisor could be viewed more as someone who is a coach, whose role is to make sure each teller or CSR uses what they learned in their training correctly, and to identify areas where employees need refresher or additional training. For tellers and CSRs, this emphasis on training may overshadow the importance of the supervisor's qualities in terms of their ability, benevolence, and integrity. The supervisors' support and evaluation of how these employees perform reinforces how employees interpret and use their training on the job. This could explain the weak correlation between perceptions of supervisor and job performance for CSRs and the lack of a nonzero linear correlation between perceptions of supervisor and job performance of tellers. The finding of a weak correlation at best between perception of supervisor and job performance may indicate how important it is for tellers and CSRs to follow bank procedures, provide good customer service, and stay in compliance with federal and state banking regulations - so important, that the primary role of the supervisor is to be a coach.

\section{Managerial Implications}

Our findings will be of interest to organizations for a number of reasons. First, they show that there is a weak positive correlation between front line employees' job performance and the perceptions they have of their immediate supervisors. Secondly, the fact there is a correlation between perceptions of supervisor and trust in supervisor for customer service representatives - but no nonzero correlation between these same factors for tellers - indicates there is a need for further research. Both of these findings have direct applicability to the employee-supervisor relationship.

In the service industry the focus of all businesses should be on providing outstanding customer service (Lytle \& Timmerman, 2006), but in practical terms, this goal appears to be an ongoing problem for many organizations. For example, according to the Accenture Global Consumer Survey which surveys organizations such as banks, wireless carriers, and utilities, the number of consumers switching from one service provider to another due to complaints about poor service increased from 49 percent in 2005 to 69 percent in 2009. The J. D. Powers and Associates 2010 U. S. Retail Banking Satisfaction Study also reported drops in customer satisfaction showing that consumers' perceptions of retail banks brand images and customer loyalty to banks have declined in four consecutive years (J.D. Powers, 2010). Having a customer oriented focus that is well executed has been found to positively affect customer satisfaction, as well as employee loyalty and job satisfaction (Johnson, 1996; Schneider et al., 2007). The results of this study suggest that two key concepts for managers should focus on are front line employees' perceptions of their immediate supervisor and trust.

In spite of the fact that they are an important link between human resource management and organizational performance, there is a lack of research on the role of the first line supervisor (Boslie et al., 2005). The fact that first line supervisors assume considerable responsibility for implementing human resource activities indicates that more needs to be understood about their role. What supervisors say and do will influence the perceptions employees have of them which, in turn, can affect an employee's work performance and how they view the organization they work for (Liden et al., 2004). According to Yang \& Mossholder (2010) when employees believe their supervisor has integrity, is reliable, and has the ability to carry out his/her job duties, employees should be able to focus on completing their job tasks satisfactorily. In the service industry first line managers have been found to be critical to an organization's success in providing quality service to their customers (Schneider et al., 2007). 
Due to the lack of a nonzero linear correlation between perceptions of supervisor and job performance for tellers and a weak correlation between perceptions of supervisor and the job performance of CSRs, it appears that one or more other factors must play a role in the job performance of tellers and CSRs. Purcell (1999) have found that there are two factors that influence employees' actions on the workplace - human resource practices and the leadership behaviors of their managers. They suggest that a closer look at the areas of human resource practices may provide some insight into what is, at most, a weak correlation between perceptions of supervisor and job performance in the current research. One of these human resource practices could be training. Training is the human resource activity that is critical to front line bank employees is training. Both tellers and CSRs need training with respect to customer service, the bank's products and procedures, and state and federal banking regulations as well as training updates when changes in any of the above occur. If training is handled by a trainer and not the immediate supervisor, this could affect the importance of the supervisor/employee relationship.

The findings of the present study's front line bank employee survey add further support to the idea that employees' trust in their supervisor plays a critical role in their relationship which was evidenced in the strong positive correlation that was found between perceptions of supervisor and trust in supervisor for CSRs. However, the stepwise regression analysis did not produce a similar finding for tellers suggesting there is a significant difference between these two groups of front line employees. The importance of training for tellers may overshadow the perceptions of supervisor and trust in supervisor relationship. One possible difference may be that tellers can ask other tellers for assistance or it may be that the difference can be explained, in part, by tellers having face-to-face contact with customers which may reinforce the importance of training and good customer service. On the other hand, CSRs work in a more isolated environment which may make them more heavily dependent upon their supervisor and may mean CSRs place greater value on their supervisors' attitudes and behaviors (ability, benevolence, and integrity).

\section{CONCLUSION}

This study has a number of limitations. First, its findings are based on only a single case study in one sector of the service industry. Therefore, this research should be extended to banks located in other regions of the United States, and also be extended to other sectors of the service industry.

Future research could proceed in a number of directions. First, an instrument with more in-depth survey items could be developed; or, one-on-one interviews with employees could be done which would likely produce richer data.

Another direction for future research would be to look at other components of human resource activities. For example, almost $66 \%$ of the respondents had worked for their bank for four years or less. Why is there a high rate of turnover? What major reasons do front line employees give for leaving their positions? It could be a factor such as pay, security issues (ex. threat of a bank robbery), or the regulatory environment in which banks operate. Future research could also investigate the effects of formal and informal evaluation of front line bank employees. Tzafrir (2005) has found that the motivation of front line employees increases when their performances are "carefully assessed and recognized". A number of employees in the survey instrument stated that they had never had a formal performance evaluation while others stated it had been over a year since the last formal evaluation. Thus, it would be interesting to learn more about the evaluation of front line bank employees.

\section{AUTHOR BIOGRAPHIES}

Betty Birkenmeier holds a MBA degree from the University of Louisiana-Lafayette, a Juris Doctorate from Louisiana State University, and a DBA from Grenoble Ecole de Management. She has 15 years of experience teaching at Texas A\&M University-Killeen, the University of Louisiana-Lafayette, Louisiana State UniversityEunice, and South Louisiana Community College. Her research interests are focused on human resource management and organizational behavior topics.

Pierre-Yves Sanséau is Professor at Grenoble Ecole de Management (France). He holds a Ph.D. and a HDR in business administration from the University of Lyon (France), a MBA (Montreal, Canada) and a M.Sc. in Political Sciences. His research interests include trust, management of technology, management of competences, working 
time, work-life integration and life-long learning. Dr Sanséau is also a research scholar at San Jose State University Graduate School of Business (California).

\section{REFERENCES}

(2010). J. D. Powers and Associates Reports: Customer loyalty and brand image decline among retail banking customers for a fourth consecutive year. Available at: http://businesscenter.jdpower.com/news/pressrelease.aspx?ID=2010068. Date accessed: June 1, 2011.

Axelrod, R. (1984). The Evolution of Cooperation. New York, NY: Basic Books.

Babin, B. J. \& Boles, J. S. (1996). The effects of perceived co-worker involvement and supervisor support on service provider role stress, performance, and job satisfaction. Journal of Retailing, 72(1): 57-75.

Bachman, J. G., Bowers, D. G., \& Marcus, P. M. (1968). Bases of supervisory power: A comparative study in five organizational settings. In A. S. Tannenbaum (Ed.), Control in Organizations. New York, NY: McGraw Hill.

Bazerman, M. H. (1993). Fairness, social comparison and irrationality. In J. K. Murnigham (Ed.), Social Psychology in Organizations: Advances in Theory and Research. Englewood Cliffs, NJ: Prentice-Hall, 184-203.

Bennis, W. G. \& Nanus, B. (1985). Leaders: The Strategy for Taking Charge. New York, NY: Harper \& Row.

Bhattacharya, R., Devinney, T. M., \& Pillutla, M. M. (1998). A formal model of trust based on outcomes. Academy of Management Review, 23(3): 459-472.

Bijlsma, F. and Costa, A. C. (2005). Understanding the trust-control nexus. International Sociology, 20(3): 259-282.

Blau, P. M. (1964). Exchange and Power in Social Life. New York: Wiley.

Blusdon, B. and Reed, K. (2003). The effects of technical and social conditions on workplace trust. International Journal of Human Resource Management, 14(1): 12-27.

Boselie, P., Dietz, G., \& Boon, C. (2005). Commonalities and contradictions in research on human resource management and performance. Human Resource Management Journal, 13(3): 67-94.

Boshoff, Ch. \& Tait, M. (1996). Quality perceptions in the financial services sector: The potential impact of internal marketing. International Journal of Service Management, 7(5): 5-31.

Bowen, D. E. (1990). Interdisciplinary study of service: Some progress, some prospects. Journal of Business Research, 20(1): $71-79$.

Butler, J. K. (1991). Towards understanding and measuring conditions of trust: Evolution of a conditions of trust inventory. Journal of Management, 17(3): 643-663.

Cho, Yoon Jik \& Ringquist, Evan J. (2010). Managerial trustworthiness and organizational outcomes. Journal of Public Administration Research and Theory, 21: 53-86.

Clark, C. S., Dobbins, G. H., \& Ladd, R. T. (1993). Exploratory field study of training motivation: Influence of involvement, credibility, and transfer climate. Group \& Organization Management, 18(3): 292-307.

Clark, M. C. \& Payne, R. L. (1997). The nature and structure of workers' trust in management. Journal of Organizational Behavior, 18: 205-224.

Colquitt, J. A., LePine, J. A., Piccolo, R. F., Zapata, C. P., \& Rich, B. L. 2012. Explaining the justice-performance relationship: Trust as exchange deepener or trust as uncertainty reducer?. Journal Of Applied Psychology, 97:1-15.

Cook, J. \& Wall, T. (1980). New work attitude measures of trust, organizational commitment, and personal need nonfulfillment. Journal of Occupational Psychology, 53: 39-52.

Crosby, L. A. \& Johnson, S. L. (2002). Going my way? Marketing Management, 11(4): 10-11.

Cummings, L. L. (1983). Performance evaluation in the context of individual trust and commitment. In F. Landry \& S. Zedeck (Eds.), Frontiers of Performance Evaluation. Hillsdale, NJ: Erlbaum, 89-93.

Cummings, L. L. \& Bromiley, P. (1996). The organizational trust inventory OTI: Development and Validation. In R. Kramer \& T. Tyler (Eds.), Trust in Organizations: Frontiers in Theory and Research. Thousand Oaks, CA: Sage, 302-330.

Dasgupta, P. (1988). Trust as a commodity. In D. Gambetta (Ed.), Trust: Making and Breaking Cooperative Relations. Cambridge, MA: Basil Blackwell, 49-72.

Davis, J. H., Schoorman, F. D., Mayer, R. C. \& Tan, Hwee Hoon (2000). The trusted general manager and business unit performance: Empirical evidence of a competitive advantage. Strategic Management Journal, 21: 563-576.

den Hartog, D. N. \& Verburg, R. M. (2004). High performance work systems, organizational culture and perceived organizational effectiveness. Human Resources Management Journal, 14: 55-78.

Dirks, Kirk T. \& Ferrin, D. L. (2001). The role of trust in organizational settings. Organization Science, 12(4): $450-467$.

Dirks, K. T. \& Skarlicki, D. P. (2004). Trust in leaders: Existing research and emerging issues. In R. M. Kramer \& K. S. Cook (Eds.). Trust and Distrust in Organizations: Dilemmas and Approaches. New York, NY: Russell Sage Foundation, 21-40

Earley, P. C. (1986). Trust, perceived importance of praise and criticism and work performance: An examination of feedback in the United States and England. Journal of Management, 12(4): 457-473).

Eisenberger, R., Fasolo, P,, \& Davis-LaMastgro, V. (1990). Perceived organizational support and employee diligence, commitment, and innovation. Journal of Applied Psychology, 75: 51-59.

Ellinger, A. E., Elmadag, Aysc B., \& Ellinger, A. D. (2007). An examination of organizations' frontline service employee 
development practices. Human Resource Development Quarterly, 18(3): 293-314.

Evenson, A., Harker, P. T., \& Frei, F. X. (1999). Effective call center management: Evidence from financial services. Working Papers - Financial Institutions Center at The Wharton School, 1-27.

Ferrin, D. L., Bligh, M. C., \& Kohles, J. C. (2007). Can I trust you to trust me? A theory of trust, monitoring, and cooperation in interpersonal and intergroup relationships. Group \& Organization Management, 32: 465-499.

French, Jr., R. P. \& Snyder, R. (1959). Leadership and interpersonal power. In D. Cartwright (Ed.), Studies in Social Power. Ann Arbor, MI: Institute for Social Research, University of Michigan, 150-167.

Gabarro, J. J. and J. Athos (1976). Interpersonal Relations and Communications. Englewood Cliffs, NJ: Prentice-Hall.

Gagnon, M. \& M., Judd (2004). Outcomes of perceived supervisor support for wood production employees. Wood Products Journal, 54(12): 172-177.

Gibb, S. (2001). The state of human resource management: Evidence from employees' views of HRM systems and staff. Employee Relations, 23(4): 318-336.

Golembiewski, R. T. \& McConkie, M. L. (1975). The centrality of interpersonal trust in group processes. In C. L. Cooper (Ed.) Theories of Group Processes. New York, NY: Wiley, 131-185.

Gould-Williams, J. \& Davies, F. (2005). Using social exchange theory to predict the effects of HRM practice on employee outcomes: An analysis of public sector workers. Public Management Review, 7(1): 1-24.

Gould-Williams, J. (2003). The importance of HR practices and workplace trust in achieving superior performance: A study of public-sector organizations. International Journal of Human Resource Management, 14(1): 28-54.

Grant, D. \& Shields, J. (2002). In search of the subject: Researching employee reactions to human resource management. The Journal of Industrial Relations, 44(3): 313-334.

Hansen, H., Sandgvik, K., \& Selnes, F. (2003). Direct and indirect effects of commitment to a service employee on the intention to stay. Journal of Service Research, 5(4): 356-368.

Johnson, J. W. (1996). Linking employee perceptions of service climate to customer satisfaction. Personnel Psychology, 49(4): 831-851.

Lawler, Lawler, E. J. (1992). Power process in bargaining. Sociological Quarterly, 33: 17-34.

Lewicki, R. J., McAllister, D. J. \& Bies, R. J. (1998). Trust and distrust: New relationship and realities. Academy of Management Review, 23(3): 438-458.

Lewicki, R. J. \& Bunker, B. B. (1996). Developing and maintaining trust in work relationships. In R. M. Kramer and T. R. Tyler (Eds.) Trust in Organizations: Frontiers of Theory and Research. Newbury Park, CA: Sage Publications, $114-$ 139.

Lewicki, R. J. \& Bunker, B. (1995). Trust in relationships: A model of trust development and decline. In B. Bunker \& J. Rubin (Eds.), Conflict, Cooperation, and Justice. San Francisco: Jossey-Bass, 133-173.

Liden, R., Bauer, T. \& Erdogan, B. (2004). The role of leader-member exchange in the dynamic relationship between employer and employee: Implications for employee socialization, leaders, and organizations. In J. Coyle-Shapiro, L. Shore, S. Taylor, and L. Tetrik (Eds.). The Employment Relationship: Examining Psychological and Contextual Perspectives. Oxford, UK: Oxford University Press, 226-252.

Locke, E. A. \& Latham, G. P. (2002). Building a practically useful theory of goal setting and task motivation. American Psychologist, 57: 705-717.

Lytle, R. S. \& Timmerman, J. E. (2006). Service orientation and performance: An organizational perspective. Journal of Services Marketing, 20(2): 136-147.

McAllister, D. J. (1995). Affect and cognition-based trust as foundations for interpersonal cooperation in organizations. Academy of Management Journal, 38(1): 24-59.

Magenau, J. M. \& Hunt, R. G. (1996). Police Unions and the Police Role. Human Relations, 49(10): 1315-1343.

Mayer, R. C., Davis, J. H., \& Schoorman, F. David (1995). An integrative model of organizational trust. Academy of Management Review, 20(3): 709-734.

Mayer, R. C. \& Davis, J. H. (1999). The effect of the performance appraisal system on trust for management: A field quasiexperiment. Journal of Applied Psychology, 84(1): 123-136.

Mayer, R. C. \& Gavin, M. B. (2005). Trust in management and performance: Who minds the shop while the employees watch the boss? Academy of Management Journal, 48(5): 874-888.

Morgan, P. \& Allington, N. (2002). Has the public sector retained its model employer status? Public Money and Management, January - March: 35-42.

Morgan, D. E. \& Zeffane, R. (2003). Employee involvement, organizational change and trust in management. International Journal of Human Resource Management, 14(1): 55-75.

Neves, P. \& Caetano, A. (2009). Commitment to change: Contributions to trust in the supervisor and work outcomes. Group \& Organization Management, 34(6): 623-644.

Nyhan, R. C. (2000). Changing the paradigm: Trust and its role in public sector organizations. American Review of Public Administration, 30(1): 87-109.

Nyhan, R. C. \& Marlowe, JR., Herbert A. (1997). Development and psychometric properties of the Organizational Trust Inventory. Evaluation Review, 21(5): 614-635.

Paul, A. K. \& Anantharaman, R. N. (2003). Impact of people management practices on organizational performance: Analysis 
of a causal model. International Journal of Human Resource Management, 14(7): 1246-1266.

Pritchard, M. P., Havitz, M. E., \& Howard, D. R. (1999). Analyzing the commitment-loyalty link in service contexts. Journal of the Academy of Marketing Science, 27(3): 333-348.

Puay, C. L., Tang, K. H., \& Jackson, P. M. (1999). An innovative framework for health care performance measurement. Managing Service Quality, 9(6): 423-433.

Purcell, J. (1999). Best practice and best fit: Chimera or cul-de-sac? Human Resource Management Journal, 9(3): 26-41.

Rich, G. (1997). The sales manager as a role model: Effects of trust, job satisfaction, and performance of salespeople. Journal of Academy of Marketing Science, 25: 319-328.

Roberts, K. H. \& O’Reilly, C. A. III (1994). Measuring organizational communication. Journal of Applied Psychology, 59: 321-326.

Robinson, S. L. \& Rousseau, D. M. (1994). Violating the psychological contract: Not the exception but the norm. Journal of Organizational Behavior, 15: 245-259.

Rowold, J. (2008). Multiple effects of human resource development interventions. Journal of European Industrial Training, 32(1): $32-44$.

Sandberg, J. (2000). Understanding human competence at work: An integrative approach. Academy of Management Journal, 43: $9-25$.

Schneider, B., Young, S. A., \& Macey, W. H. (2007). Service smarts. Marketing Management, 16(4): 29-34.

Schoorman, F. D., Mayer, R. C., \& Davis, J. H. (1996). Empowerment in veterinary clinics: The role of trust in delegation. Paper presented at the $11^{\text {th }}$ annual meeting of the Society for Industrial and Organizational Psychology, San Diego, CA.

Sherwood, A. L. \& DePaolo, C. A. (2005). Task and relationship-oriented trust in leaders. Journal of Leadership and Organizational Studies, 12(2): 65-81.

Smith, J. B. \& Barclay, W. B. (1997). The effects of organizational differences and trust on the effectiveness of selling partner relationships. Journal of Marketing, 61: 3-21.

Tan, H. H. \& Tan, C. S. (2000). Toward the differentiation of trust in supervisor and trust in organization. Genetic, Social, and Psychology Monographs, 126: 241-260.

Tzafrir, Shay S. (2005). The relationship between trust, HRM practices and firm performance. International Journal of Human Resource Management, 16(9): 1600-1622.

Tzafrir, S. S. \& Dolan, S. L. (2004). Trust me: A scale for measuring manager-employee trust. Management Research, 2(2): $115-132$.

Tzafrir, S. S., Harel, Gedaliahu H., Baruch, Y., \& Dolan, S. L. (2004). The consequences of emerging HRM practices for employees' trust in their managers. Personnel Review, 33(5/6): 628-647.

Tzafrir, Shay S. \& Gur, Amit B. A. (2007). HRM practices and perceived service quality: The role of trust as a mediator. Research and Practice in Human Resource Management, 15(2): 1-20.

Vlaar, W. L., Van den Bosch, F. A. J., \& Volberda, H. W. (2007). On the evolution of trust, distrust, and formal coordination and control in interorganizational relationships: Toward an integrative framework. Group \& Organization Management, 32: 407-429.

Wright, M. P., Gardner, M. T., \& Moynihan, M. L. (2003). The impact of HR practices on the performance of business units. Human Resource Management Journal, 13(3): 21-36.

Yang, J. \& Mossholder, K. W. (2010). Examining the effects of trust in leaders: A bases-and-foci approach. The Leadership Quarterly, 21: 50-63.

Zeithaml, V. A. \& Bitner, M. J. (2009). Services Marketing: Integrating Customer Focus Across the Firm, 5th. Boston, MA: McGraw-Hill.

Zohar, D. \& Luria, G. (2004). Climate as a social-cognitive construction of supervisory safety practices: Scripts as proxy for behavior patterns. Journal of Applied Psychology, 89: 322-333. 